\title{
An Empirical Investigation on the Relation between Disclosure and Financial Performance of Islamic Banks in the United Arab Emirates
}

\author{
Mosab I. TABASH ${ }^{1}$
}

Received: February 23, 2019 Revised: September 16, 2019 Accepted: September 24, 2019

\begin{abstract}
The paper examines the level of disclosure on Islamic banks' performance in the United Arab Emirates (UAE). The data was collected through content analysis of annual reports and financial statements of all fully-fledged Islamic banks working in the UAE over the period 2009 to 2013. Return on Assets is used as a proxy for the performance of Islamic banks while disclosure index is used as a proxy for Islamic banks' disclosure. Also, predetermined variables are used in the study like Size, Deposits, Non-Performing Investments and Capital to Risk Weighted Assets Ratio. Two-Stage Least-Square regression method is used to check the interdependence relationships between disclosure and performance of Islamic banks in the UAE. The results show a significant relationship between performance and disclosure in the UAE Islamic banks. Our regression results show that Islamic banks with higher levels of disclosure lead to higher operating performance. Furthermore, the performance has a great impact on the level of disclosure which means Islamic banks with high performance measures will disclose more information for investors and other institutions in order to reduce the cost of equity and increase their values in the market. This study is considered as a battery for further studies in the relationship between disclosure and financial performance of Islamic banks at a global level.
\end{abstract}

Keywords : Islamic banks, Disclosure, Performance, Two-Stage Least-Square (2SLS), UAE

JEL Classification Code : C33, G32, G34

\section{Introduction}

In the area of management and finance literature, many theories have explained the value and the benefit of the banks' disclosure. The agency theory states that there is a conflict of interests between the shareholders and the managers with respect to investment decisions of any corporations. This conflict of interests may lead to negative impacts on the corporation's image and value (Jensen \& Meckling, 1976). Therefore, managers who are working in the corporations should disclose all and full information of their investment decisions to the shareholders of the company (Healy, Hutton, \& Palepu, 2001).

1 First Author and Corresponding Author, Assistant Professor of Finance, College of Business, Al Ain University of Science and Technology, UAE. [Postal Address: P.O. Box: 64141, Al Ain, UAE] Email: Mosab.tabash@aau.ac.ae

(c) Copyright: Korean Distribution Science Association (KODISA)

This is an Open Access article distributed under the terms of the Creative Commons Attribution Non-Commercial License (http://Creativecommons.org/licenses/by-nc/4.0/) which permits unrestricted noncommercial use, distribution, and reproduction in any medium, provided the original work is properly cited.
From perspective of another theory of the relationship between disclosure and financial performance of the corporations, the signaling theory states that the managers have more information about the real value of the company than others do. So, they are benefiting from this information asymmetry to implement their interests. Therefore, this theory claims that managers have to disclose all relevant information from financial report and statements to the current and potential investors. Also, it states that managers who provide incorrect signals will be punished (Hughes, 1986). Furthermore, there are two theories "legitimacy theory" and "the stakeholders' theory". The legitimacy theory deals with the voluntary disclosure of all information about its social, economic, environmental issues related to the society (Gray, Kouhy, \& Lavers, 1995). The stakeholders' theory provides a demonstration of accountability to stakeholders. It stated that the company should disclose all its information to keep a good relationship with its stakeholders (Freeman, 1994). Islamic finance, particularly Islamic banking, is a different model of financing which is based on equity not on debt. Therefore, it is very important 
for all corporations working in Islamic finance environment to give more attention for disclosure about its financial statement and reports to the equity holders in order to mitigate the conflict of interest's issues, agency problems and to achieve good control of the firm.

Any good information regarding the expected return disclosed might affect shareholders and potential investors. In structuring the investment contract, firms have choices whether to choose more or less capital and the composition of capital for each type of contract. Typically, firm's capital structure consists of equity and debt contract. The equity contract involves cost of equity while for debt contract, cost of debt is incurred. Cost of capital is used to measure return to be paid to the capital providers. The expected return that must be achieved should be more that the cost of capital in order to satisfy them. Islamic banks are considered as equity banks and not engaged in debt transactions. Therefore, only equity transactions are considered for their investments. The benefits of disclosure within the banking systems are to correct any bank misevaluation and to increase institutional interest and liquidity of the bank.

Increasing information disclosure by banks is expected to increase for growing in performances as a result of monitoring by outsiders. In this case, disclosures assist the banks to increase their values. Banks also tend to minimize their cost of capital (Baumann, 2006). Thus, the extent to which bank comply with the capital requirement and at the same time heavily observed their risk-taking activities, discloses information or level of disclosure to the user is significant for the market (user) to discipline bank.

In the current study, the relationship between disclosure and performance of Islamic banks in the UAE are addressed. The paper is structured into 6 sections. Introduction is given in section 1. Section 2 presents the current status of Islamic banking in the UAE. Section 3 provides the literature review of the current study. Section 4 gives the methodology of the paper. Section 5 shows the results of the study. Conclusion is given in section 6 .

\section{Islamic Banking and Economic Environment in the United Arab Emirates}

The Islamic banking is a banking system based on equity type of financing. Currently, Islamic banking has footprints in more than 75 countries around the globe. It shows its stability under different financial shocks and volatility. Moreover, Islamic banks have played a major role in enhancing economic growth of the UAE, bringing Foreign Direct Investments (FDI) into the UAE lately (Tabash \& Dhankar, 2014a, 2014b). The UAE government pays more attention and interest in Islamic banking industry. And in this regard, Dubai is working well to become a center for Islamic finance industry at a global level. Also, The UAE government supports the Islamic banking industry growth in its strategic plan 2021 (Emirates diary, 2015). As we can see from Figure 1, the assets of Islamic banks have increased from 1990 to 2014 with a positive trend.

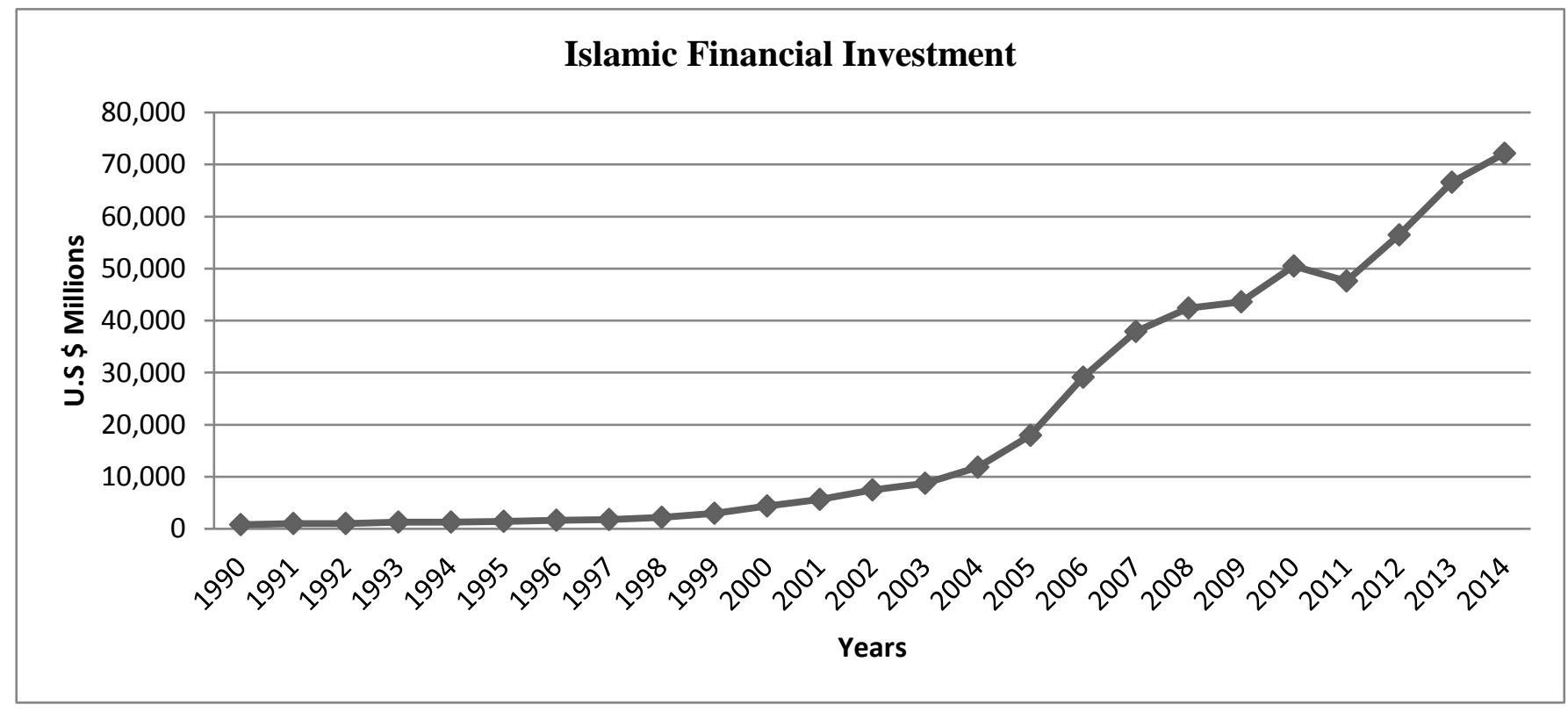

Figure 1: Islamic financial investments in UAE (1990-2014)

In the UAE, there are 23 local banks and 22 international banks. Out of 23 banks, 7 are fully-fledged Islamic banks and the rest of banks have both systems, Islamic and traditional operations (Emirates diary, 2015). With respect to the economic environment, the UAE is one of the Arab countries. It is considered the second economy of the Middle 
East. It is the seventh-largest in the world in oil reserves (OPEC, 2014). The UAE joined the General Agreement on Tariffs and Trade (GATT) in 1994 and the World Trade Organization (WTO) in 1996. There are two kinds of legislations regulating the financial accounting practices of the banks working in the country. Firstly, the Central Bank of the UAE (CBUAE) which puts regulations governing the preparation of the financial reports in compliance with the International Financial Reporting Standards (IFRS) (Hussein No Reference, 2002). All the financial and non-financial corporations are required to comply with the IFRS 7 (financial instruments disclosure), as well as other standards about segment reporting and contingencies so they are all under the pressure to disclose their risk information (Hassan, Romilly, Giorgioni, \& Power, 2009).

Secondly, the Emirates Securities and Commodities Authority (ESCA) sets registration conditions affecting the registration, as well as the regulations concerning the disclosure and transparency (UAE Federal Law No. 4 of 2000) and encourages the capital market registrants to disclose their information and ensure an appropriate level of transparency to raise the investors' confidence. Regarding Islamic banks, they are preparing and presenting their financial statements and reports in accordance with International Financial Reporting Standard (IAS 34) and Accounting and Auditing Organization of Islamic Financial Intuitions (AAOIFI). The reason of exploring the disclosure and banks' performance in the UAE as an emerging market is to test the current and expected situations of UAE Islamic banks and the degree of disclosure.

\section{Literature Review}

Most studies have mixed views on the link between the performance of banking sector and the level of disclosure. Most businesses environments depend on the availability of information to invest and work. Therefore, this study is done to assess and determine how the interdependent relationship between disclosure and banks' performance particularly in the context of Islamic banks in the UAE.

Since the introduction of BASEL II in 1999, the topic of market discipline to the banking institution has received a huge interest. The discussions on bank capital and disclosure arises as one approach for market discipline (Baumann \& Nier, 2004; Nier \& Baumann, 2006; Hirtle, 2007). For banks, capital decision is subjected to regulatory requirements. Bank capital is not only used as a source of financing but it is also used as tool in managing risks. Therefore, holding capital stands as a buffer against risks and malfunction. Therefore, management discretions are important as the liability side of banks' balance sheet is adjusted with capital amount.

Banks that is able to absorb the losses that is hidden, able to reduce cost of capital, their performance would be higher. When the cost of capital is used by the market in determining the possible return out of the investment, bank performance is directly affected. Today, the impact of increased level of disclosure to the cost of capital has long been discussed in disclosure literature. But for Islamic banks, such debate is still limited. This study tries to bridge the gap in disclosure work by showing the empirical evidence on disclosure and banks' performance. As a rule of thumb, theories suggest that cost of capital is affected by information disclosed by firms. While the cost of capital has a direct relationship with firm's value. Firms that disclose more information is found to be decreased in their cost of capital. Although, the result is subjected to major arguments in several empirical works (Botosan, 1997; Diamond \& Verrecchia, 1991; Sengupta, 1998; Botosan \& Plumlee, 2002; Peterson \& Plenborg , 2006 ; Hassan et al., 2009). Botosan (1997) presented the difficulties in getting the actual estimation for cost of equity. As a result, cost of capital that documented negative relations to disclosure is difficult to be defended. Botosan and Plumlee (2002) reexamined previous work on cost of equity capital with various types of disclosure. They didn't find any association between cost of equity and disclosure while positive association result is found only for timely disclosure.

In 2004, a study of Al-Tuwaijiri, Christensen, and Hughes (2004) suggested that disclosure is positively associated with performance while Hassan et al. (2009) found that disclosure is negatively related to banks' performance. Again, Al-Tuwaijiri et al. (2004) have checked performance and disclosure simultaneously in exploring the relation between disclosure and performance in the study of environmental reporting. Their findings reveal that firms who performed well had a good disclosure measures.

In banking studies, Baumann and Nier (2004) found that the benefits of disclosure lead to lower risk and higher riskadjusted returns. Hirtle (2007) has examined the link between the amount of information disclosed by banks and their effect on risk and performance. Results showed that greater disclosure is associated with more efficient risk taking and thus improved risk-return tradeoffs. Both, Baumann and Nier (2004) and Hirtle (2007), however concentrated on risk disclosure in annual report and focused on listed banks in their studies.

Further, Lu, Liao, and Yang (2007) examined relationship among 3 variables, ownership structure, disclosure and performance. The simultaneous estimation approaches used by the authors showed that a positive relationship between disclosure and performance is documented. Another study done by Hassan et al. (2009) who found a negative relationship between disclosures and firm's value. Further, a study of Nurul and Raudah (2012) discussed the relationship between disclosure and Islamic banks' performance in case of Malaysia for Islamic banks working in Malaysia under the period 2001 to 2006. They used the simultaneous equations model for their study with the help of pooling regression model, fixed/random effect models. Their results indicated that there is a link between disclosure and performance of Islamic banks and most of 
their results are against theories of finance in context of risk, banks' size and deposits.

In another study done by Srairia (2015), he investigated the impact of the level of corporate disclosure on bank performance by constructing a corporate governance disclosure index (CGDI) for 27 Islamic banks operating in five Arab Gulf countries. Content analysis on the banks' annual reports for 3 years (2011-2013) has been used. The results showed that Islamic banks connected to $54 \%$ of the attributes addressed in the CGDI. The most frequently reported and disclosed elements are Shariah Supervisory Board (SSB) followed by board structure and risk management. The findings showed only the United Arab Emirates and Bahrain have a higher level of CGDI. It is concluded that Islamic banks with higher levels of corporate governance disclosure reports have high operating performance measured by Return on Assets (ROA) and Return on Equity (ROE).

Recently, Ellili and Nobanee (2017) have discussed the degree of corporate sustainability disclosure for listed banks in the UAE during 2003-2013. Their results showed that the sustainability disclosure level affected significantly and positively the banking performance of conventional banks but the picture is not the same for Islamic banks. Further, the same authors examined the degree of the corporate risk disclosure and its impact on the banking performance using annual data of banks listed on the UAE financial markets: Abu Dhabi Stock Exchange (ADX) and Dubai Financial Market (DFM) during the period 2003-2013.

The authors performed the content analysis of the annual reports and financial statements to measure the degree of the corporate risk disclosure. Additionally, they used the panel data regressions to analyze the impact of the corporate risk disclosure on the performance of the UAE banks. Their results showed low degree of the overall corporate risk disclosure index, strategic risk disclosure index, operational risk disclosure index, damage risk disclosure index, and risk management disclosure index for UAE listed banks.

The current study expands the coverage of disclosure to not just risk disclosure but also the financial information disclosed in annual reports and financial statements of Islamic banks working in the UAE. Further, the study focuses on Islamic banks in which literature work is still limited particularly in the area of disclosure and bank performance. In addition, the paper develops insights about the mutual relationship between disclosure and performance by adapting panel data using simultaneous equations approach. The paper argument is stated that the benefits of disclosure through lowered cost of capital which further increased performance. At the same time, performance of bank determines to what extent disclosure have been made. Thus, additional evidence on the interdependent relationship of disclosure and performance to Islamic banks is hoped to be produced. Taken together, the objective of this study is to examine the interdependent relationship between disclosure and bank performance using panel simultaneous equation.

\section{Data and Methodology}

\subsection{Data}

The data was collected through content analysis of annual reports and financial statements of all fully-fledged Islamic banks working in the UAE over the period 2009 to 2013.

\subsection{Hypotheses}

In constructing hypothesis, we test the interdependent link between information disclosure and performance of Islamic banks of UAE. The interdependent hypotheses are stated as follows:

H1: Islamic banks' performance has a significant association with disclosure in the UAE.

H2: The disclosure has a significant association with Islamic banks' performance in the UAE.

\subsection{Variables Selection}

The cost of capital for Islamic banks is different from different types of contracts. Therefore, the expected relationships between performance and disclosure might also be different. In order to construct those relationships, the study considers a simultaneous equation approach. The equations are adopted from Lu et al. (2007), Al-Tuwaijiri et al. (2004) and Nurul and Raudah (2012) studies. This study argued that mutual relationship exists. In this situation, simultaneity problem might arise where disclosure and performance is both endogenously determined. For that, a simultaneous equation model which includes analysis of panel two-stage least-square might better suit the estimation. Thus, firstly, the initial model is based on model developed by Al-Tuwaijiri et al. (2004) with few adjustments as follows:

$$
\begin{aligned}
& \mathrm{DISC}=\mathrm{f}(\text { PERF, predetermined variables }) \ldots \ldots(1) \\
& \mathrm{PERF}=\mathrm{f}(\text { DISC }, \text { predetermined variables }) \ldots \ldots(2)
\end{aligned}
$$

From the above two equations, there are two models stated as disclosure model (DISC equation) and performance model (PERF equation). Before proceeding to the structural equations, discussions of endogenous variables, exogenous variables and predetermined variable is presented.

\subsubsection{Endogenous and Exogenous Variables}

The endogenous variables stated in the equation above are disclosure level (DISC) and bank performance (PERF). Firstly, the ultimate responsibility of Islamic banks is as a trustee to the creator, and for the banks' stakeholders as a 
whole, it is essential that they should perform to meet objectives of diverse stakeholders including their shareholders, depositors, borrowing customers and employees. Thus, a positive relationship is expected. Disclosure will also benefit banks when cost of capital (fund) is lowered. In this case, performance is expected to increase which will lead to an increase in customers confident. Further, it leads to more services and finances. This study proposes performance using the Returns on Assets (ROA) as accounting performance as it is more directly related to banks' survivals. While for the disclosure for Islamic banks', (Disclosure index) in the UAE is measured through the procedure used by Wallace and Naser (1995). The voluntary disclosure and mandatory disclosures (minimum requirement by central bank of UAE) are used. International Accounting Standards (IAS) and Accounting and Auditing Organizations for Islamic Financial institutions (AAOIFI) are also used. Disclosure index is calculated by dividing the total numbers of items disclosed by the total maximum numbers of items applicable as formulated by the below equations.

(a) The total numbers of items disclosed; (b) the total maximum numbers of items applicable. Both can be calculated from the following equations:-

$$
\begin{aligned}
& \mathrm{TD}_{\mathrm{it}}=\sum_{i=1}^{n} \mathrm{~d}_{\mathrm{it}} \\
& \mathrm{MS}_{\mathrm{it}}=\sum_{i=1}^{m} \mathrm{D}_{\mathrm{it}}
\end{aligned}
$$

Where:

$\mathrm{TD}=$ Total numbers of items disclosed

MS = Total maximum numbers of items applicable

$\mathrm{d}$ =scores of item disclose, 1 (disclosed) and 0 (not disclosed)

$\mathrm{D}=$ scores for each applicable items, 1 for each items

$\mathrm{n}=$ the number of disclose item

$\mathrm{m}=$ the number of applicable items which the company expected to disclose.

For applicable item, where an item is not disclose due to it is not applicable, it is concluded that the item is not relevant to the index. Therefore, it is not expected to be disclosed and not calculated as the number of applicable items. On the other hand, if an item is applicable, stated somewhere in the annual report, but has not been disclosed, the item falls under the item which is applicable (m). The item will be given scores of 1 for item applicable (D), and 0 scores for item disclosed (d).

The relative level of disclosure by each bank can be calculated by dividing the total numbers of items disclosure (TD) by the maximum numbers of items applicable (MS).

$$
\mathrm{DISC}_{\mathrm{it}}=\mathrm{TD}_{\mathrm{it}} / \mathrm{MS}_{\mathrm{it}}
$$

DISC $=$ Disclosure level
$\mathrm{TD}=$ Total numbers of items disclosed

MS $=$ Total maximum numbers of items applicable

\subsubsection{Predetermined Variables}

Table 1 shows the predetermined variables used in the study model. Capital to the risk weighted assets ratio variable (CRAR) stands as a tool to ensure that it can absorb a reasonable amount of loss and complies with statutory capital requirements. To gain customers confidence and comply with the regulatory requirement, the CRAR should be at an acceptable risk condition. Thus, it is expected to lead for better performing bank as bank failure and riskiness rate are reduced.

Log (SIZE) and log (deposits), which means the total assets of any bank has associated with increased disclosures and performance in several disclosure studies such as in Cooke (1993) and Akhtaruddin (2005). It is due to the high expectations of society for more information as a monitoring mechanism and significance of the big firms in the industry or to one country. Non-performing investments (NPI) variable is used to measure the asset quality of the banks. As financing constitutes the largest portion of banks asset, huge amount of non performing investments or non-performing loans will deteriorate the bank's asset. Ngo (2006) argued that NPI is key element in bank failures. Based on signaling theory, by adding more information to support their profitable conditions, it can convince the stakeholder where they are actually in that favorable condition. Thus, in the case of NPI, the more NPI the bank have, less information is produced as they are not in favorable condition.

Table 1: Predetermined variables used in the study

\begin{tabular}{|c|l|l|}
\hline Variables & Notations & \multicolumn{1}{c|}{ Measure } \\
\hline \multirow{4}{*}{$\begin{array}{l}\text { Predetermined } \\
\text { Variables }\end{array}$} & CRAR & $\begin{array}{l}\text { Capital to the risk weighted } \\
\text { assets ratio (CRAR). }\end{array}$ \\
\cline { 2 - 3 } & $\begin{array}{l}\text { Log } \\
\text { (Deposits }\end{array}$ \\
\cline { 2 - 3 } & $\begin{array}{l}\text { Log } \\
\text { (SIZE }\end{array}$ & $\begin{array}{l}\text { Total deposits of Islamic } \\
\text { banks' operations }\end{array}$ \\
\cline { 2 - 3 } & Log(NPI) & $\begin{array}{l}\text { Total asset of Islamic banks' } \\
\text { as disclosed by Islamic banks }\end{array}$ \\
\hline
\end{tabular}

\subsection{Methodology}

The current study uses annual report of full-fledged Islamic banks working in the UAE from 2009 to 2014. All of the seven selected Islamic banks are subjected to the requirements of Central bank of UAE, AAOIFI and IFSB standards. The study argued that may be a mutual relationship exists between disclosure and performance of Islamic banks in the UAE. In this situation, simultaneity problem might arise where disclosure and performence is both endogenously determined. For that, a simultaneous equation which include analysis of panel Two-Stage LeastSquare (2SLS)) might better suits the estimation. The above variables are used to construct the below model. 


$$
\mathrm{PERF}_{i t}=\beta_{0}+\beta_{1} \mathrm{DISC}_{\mathrm{it}}+\beta_{2} \mathrm{CRAR}_{\mathrm{i}(\mathrm{t}-1)}+\beta_{3} \mathrm{~L}_{-} \mathrm{DEP}_{\mathrm{it}}+
$$$$
\beta_{4} \mathrm{~L}_{-} \mathrm{SIZE}_{\mathrm{it}}+\varepsilon_{\mathrm{it}}
$$

DISC $_{2 \mathrm{it}}=\alpha_{0}+\alpha_{1}$ PERF $_{2 \mathrm{it}}+\alpha_{3} \mathrm{DISC}_{2 \mathrm{it}(\mathrm{t}-1)}+\alpha_{4} \mathrm{~L}_{-} \mathrm{NPI}_{2 \mathrm{it}}+$

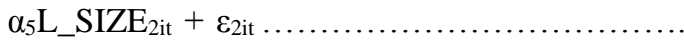

Where

- 1,2..n, refers to units of cross-section for numbers of Islamic banks in UAE

$\cdot t=1,2, . . t$, refers to times

- DISC $_{\mathrm{it}}$ refers to disclosure for $\mathrm{i}$ bank individual and $\mathrm{t}$ times

- DISCit-1 refers to the lagged control disclosure for i bank individual and $t$ times

- PERF ${ }_{\text {it }}$ refers to performance for $\mathrm{i}$ bank individual and $\mathrm{t}$ times

- CRAR i(t-1) refers to Capital to Risk Weighted Assets Ratios for i bank individual and t times

- $\log _{-} \mathrm{DEP}_{\text {it }}$ refers to natural $\log$ of deposits for i bank individual and $t$ times

- Log_SIZEit refers to natural $\log$ of size for i bank individual and $t$ times

- Log_NPF to natural log of non-performing financing for i bank individual and $t$ times

- $\varepsilon$ it is a error terms for each banks and times. Assume that has a constants variant.

In exploring the mutual relationship, the relationship between these two variables and the possible endogeneity of the variables need to be found. To investigate the effect and the possible endogeneity of each independent variable, the 2SLS system is used where we regress all the equations jointly. The endogenous variables are DISC and PERF, the exogenous variables are CRAR, $\log _{-}$DEP, DISC $(t-1)$, Log_NPF and Log_SIZE $i t$. Referring to the structural form of the equation in (1) and (2). Each endogenous variable becomes as follows:

$$
\operatorname{PERF}_{\mathrm{it}}=\Pi_{0}+\hat{\Pi}_{2} \mathrm{CRAR}_{\mathrm{it}(-1)}+\Pi_{3} \mathrm{~L} \_\hat{D E P}_{\mathrm{it}}+\Pi_{4} \mathrm{~L} \_\mathrm{SIZE}+\mathrm{u}_{\mathrm{it}} \ldots \ldots
$$

$$
\begin{aligned}
& \wedge \wedge \wedge \wedge \\
& \text { DISC }_{2 \mathrm{it}}=\Pi_{0}+\Pi_{2} \mathrm{DISC}_{2 \mathrm{i}(\mathrm{t}-1)}+\Pi_{3} \mathrm{~L}_{-} \mathrm{NPI}_{2 \mathrm{it}}+\prod_{4} \mathrm{~L}_{-} \mathrm{SIZE}_{2 \mathrm{it}}+\mathrm{u}_{2 \mathrm{it}}
\end{aligned}
$$

In stage 2 we replace the endogenous variables $\left(\mathrm{PERF}_{\mathrm{it}}\right.$ and $\mathrm{DISC}_{2 \mathrm{it}}$ ) in the original (structural) equations by their estimated values from the preceding two regressions and then run the 2SLS as follows (Gujarati , 2005):

$\wedge$

$\mathrm{PERF}_{\mathrm{it}}=\beta_{0}+\beta_{1} \mathrm{DISC}_{\mathrm{it}}+\beta_{2} \mathrm{CRAR}_{\mathrm{it}(\mathrm{t})}+\beta_{3} \mathrm{~L}_{-} \mathrm{DEP}_{\mathrm{it}}+\beta_{4} \mathrm{~L}_{-} \mathrm{SIZE}_{\mathrm{it}}+\varepsilon_{\mathrm{it}}$

$\mathrm{DISC}_{2 \mathrm{it}}=\delta_{0}+\delta_{1} \mathrm{PERF}_{2 \mathrm{it}}+\delta_{2} \mathrm{DISC}_{2 \mathrm{it}(-1)}+\delta_{3} \mathrm{~L}_{-} \mathrm{NPI}_{2 \mathrm{it}}+\delta_{4} \mathrm{~L}_{-} \mathrm{SIZE}_{2 \mathrm{it}}+\varepsilon_{2 \mathrm{it}}$

\section{Empirical Results and Discussions}

Table 2 presents the results of descriptive statistics involving the mean, standard deviation, maximum and minimum values for all variables under the study. The maximum value is 0.8912 for the performance of Islamic banks of the UAE with standard deviations 0.1251 which is considered good for the Islamic banking industry working in the UAE. The same picture could be drawn for the disclosure variable.

The statistics for minimum values for the predetermined variables are all positive except NPI variable which means some banks have suffered from non performing financing. The number of observations is 35 for each variable which means 210 observations for the whole model. Table 3 shows the correlation coefficient for all variables is small and less than 0.75 which indicate there is no multicollinearity of the data (Gujarati, 2005). It is observed from the data there is a correlation between Performance and Disclosure. This is expected that the two interdependent variables will move in a similar manner.

Table 2: Descriptive Statistics

\begin{tabular}{|l|l|l|l|l|l|l|}
\hline \multicolumn{1}{|c|}{ Variables } & \multicolumn{1}{c|}{ PERF } & \multicolumn{1}{c|}{ DISC } & \multicolumn{1}{c|}{ CRAR } & \multicolumn{1}{c|}{ Log(DEP) } & \multicolumn{1}{c|}{ Log(SIZE) } & \multicolumn{1}{c|}{ Log(NPI) } \\
\hline Mean & 0.4312 & 0.8059 & 12.1780 & 5.0676 & 9.0677 & 4.5668 \\
\hline Std. Dev. & 0.1251 & 0.2124 & 4.1221 & 1.3124 & 2.2142 & 2.6275 \\
\hline Max & 0.8912 & 0.9145 & 20.1214 & 7.3785 & 10.5212 & 6.1792 \\
\hline Min & 0.1234 & 0.6252 & 1.0121 & 2.1457 & 7.1457 & -2.1458 \\
\hline Observations & 35 & 35 & 35 & 35 & 35 & 35 \\
\hline
\end{tabular}

Table 3: Correlation Matrix

\begin{tabular}{|l|l|l|l|l|l|l|}
\hline & \multicolumn{1}{|c|}{ PERF } & DISC & CRAR & Log(DEP) & Log(SIZE) & Log(NPI) \\
\hline PERF & 1.00 & & & & & \\
\hline DISC & 0.72 & 1.00 & & & & \\
\hline CRAR & 0.32 & 0.25 & 1.00 & & & \\
\hline Log(DEP) & 0.12 & 0.15 & 0.55 & 1.00 & & \\
\hline Log(SIZE) & 0.45 & 0.45 & 0.32 & 0.66 & 1.00 & \\
\hline Log(NPF) & -.012 & -.22 & -.11 & -.41 & -.02 & \\
\hline
\end{tabular}


In order to test the relations among the variables, the 2SLS method has been used to find out the connections between variables. The results are shown in Table 4. We can depict from the performance model that the Disclosure has a positive and significant relationship with the performance of Islamic banks since the $\mathrm{P}$ value is 0.0000 less than $(0.05)$ level of significance. Therefore, we accept the first hypothesis that the disclosure has a significant association with banks' performance of the UAE Islamic banks. This result is consistent with the others studies of literature like Lu et al. (2007), Al-Tuwaijiri et al. (2004), Srairia (2015), and Ellili and Nobanee (2017). It shows that the disclosure leads to better performance of Islamic banks in the UAE which is consistent with the theory. There is also an evidence of positive and significant relationship between Log (SIZE), LOG (DEP) and PERF (P value equals 0.000 and less than $<.05$ for the two variables) which means an increase in assets and deposits in Islamic banks leads to an increase in performance of Islamic banks in the UAE. This is an indication for good and positive Islamic banks' assets growth in the last years in the Middle East and the world. These results are also supported by Cooke (1993) and Akhtaruddin (2005).

With respect to the link between lagged Capital to Risk Asset Ratio CRAR (-1) and performance of Islamic banks of UAE, the relationship is positive and significant between CRAR (-1) and performance of Islamic banks in the UAE since $P$ value is 0.0000 is less than 0.05 level of significance. This means a good capital adequacy ratio of Islamic banks is leading to better performance in the long-run. This result is also consistent with Baumann and Nier (2004) and Hirtle (2007). If we look at the disclosure model, we can report the following results.

The performance has a great impact of the level of disclosure where $\mathrm{P}$ value is 0.000 less than (0.05) level of significant which is consistent with the previous studies and theories since Islamic banks with high performance measures will disclose more information for investors and other institutions in order to reduce the cost of equity and increase their values in the market. So, the second hypothesis is accepted that the disclosure has a significant association with Islamic banks' performance of the UAE. This is consistent with studies like (Botosan, 1997; Diamond \& Verrecchia, 1991; Sengupta, 1998; Botosan \& Plumlee, 2002; Peterson \& Plenborg, 2006; Hassan et al., 2009). When, we control for the lag variable (DISCi (t-1)), in DISC model, the results is significant at $P$ value 0.01 less than 0.05 level of significant. It means that the previous disclosure of Islamic banks is vital for the next years as well
Table 4: Panel Two-Stage Least Squares Regression Result for DISC and PERF

\begin{tabular}{|c|c|c|c|c|}
\hline & \multicolumn{2}{|l|}{ PERF } & \multicolumn{2}{|l|}{ DISC } \\
\hline & Coefficient & P value & Coefficient & $P$ value \\
\hline Constant & 0.3492 & $0.0125^{\star *}$ & 0.6644 & $0.0000^{* *}$ \\
\hline DISC & 0.1265 & $0.0000^{* *}$ & & \\
\hline PERF & & & 6.1252 & $0.00178^{\star *}$ \\
\hline $\operatorname{CRAR}(-1)$ & 0.01245 & $0.0087^{\star \star}$ & & \\
\hline $\log (D E P)$ & 0.3542 & $0.0000^{* *}$ & & \\
\hline Log(SIZE) & 0.61487 & $0.0000^{* *}$ & -0.01987 & $0.0000^{* *}$ \\
\hline DISC $(-1)$ & & & 0.2245 & $0.0147^{\star \star}$ \\
\hline Log(NPF) & & & -0.2345 & $0.0000^{* *}$ \\
\hline F statistic & 7.17 & & 9.19 & \\
\hline P-Value & 0.0000 & & 0.0000 & \\
\hline $\mathrm{R}^{2}$ & 0.8426 & & 0.8732 & \\
\hline
\end{tabular}

For $\log$ (SIZE) and Log (NPI) both are negative and significant ( $\mathrm{P}$ value for both variables less than 0.05 level of significance) in explaining the level of disclosure of Islamic banks of UAE. These results are consistent with the theory. Regarding the fitness of the study models, the values of $R^{2}$ for the two models are $0.8426,0.8732$ for performance and disclosure models, respectively, which means that the model is a good fit for the explanatory variables. It also means that $88.26 \%$ and $87.32 \%$ of the variability in performance and disclosure are explained by CRAR (-1), Log (DEP), Log (SIZE), DISC (-1), and Log (NPI). It is also indicated that the overall model is significant and the independent variables are jointly affecting the performance and disclosure of Islamic banks in UAE. It is clear from the Table 4 that $\mathrm{F}$-statistics for the two models are 7.17 $(\mathrm{p}<0.05)$ for DISC and $9.19(\mathrm{p}<0.05)$ for DISC. We reject the null hypothesis that all coefficients are zero and accept that the regression model is significant. Based on the above findings and discussions, disclosure is one of the factors that determine performance and performance is a factor to increase the disclosure level. Since, our expectations are that the two model PERF and DISC are interrelated which is supported by the results of the simultaneous equations model using the 2SLS.

The role of disclosure as a monitoring mechanism is seen to contribute for bank performance. It is approved when disclosure and performance is endogenously determined, both effect each other's. Thus, most of the findings are consistent with the theory.

\section{Conclusion}

The current study shows empirically the interdependent relationships between disclosure and performance of Islamic banks in the UAE. The Two-Stage Least Square (2SLS) 
analysis is used to reach the reliable results by solving the endogeneity biased and expected to provide interdependent relationships of performance and disclosure. The results show a significant relationship between performance and disclosure in the UAE Islamic banks. Moreover, the importance of market discipline and disclosure is one of the important elements that are emphasized by the regulatory agency, particularly for Islamic banking industry.

To enhance market discipline, the role of disclosure should be taken in a great importance for the benefit of the industry as well as to the UAE country as a whole. The results of the paper are very important for Islamic finance industry since it is in early stages and it is growing fast. Therefore, the disclosure is very important for the progress and development of the Islamic banking industry. These results help the Islamic banks to optimally disclose their information and improve the quality of their sustainability measures. The findings of this paper also give more insights and a better understanding of risk disclosure practices in the UAE and help the banks to optimally disclose their risks, improve the quality of their disclosure practices and enhance the quality of their financial reports.

\section{References}

Al-Tuwaijiri, S. A., Christensen, T. E., \& Hughes, K. E. (2004). The relations among environmental disclosure, environmental performance and economic performance: A simultaneous equations approach. Accounting, Organizations and Society, 29(1), 447-471.

Akhtaruddin, M. (2005). Corporate Mandatory disclosure practices in Bangladesh. The International Journal of Accounting, 40(1), 399-422.

Baumann, U., \& Nier, E. (2004). Disclosure, volatility, and transparency: An empirical investigation into the value of Bank Disclosure. FRBNY Economic Policy Review, 10(2), 31-45.

Baumann, U. (2006). Market discipline, disclosure and moral hazard in banking. Journal of Financial Intermediation, 15(1), 332-361.

Botosan, C. A. (1997). Disclosure level and the cost of equity capital. The Accounting Review, 72(3), 323-349.

Botosan, C. A., \& Plumlee, M. A. (2002). A re-examination of disclosure level and expected cost of capital. Journal of Accounting Research, 40(1), 21-40.

Cooke, T. E. (1993). Disclosure in Japanese corporate annual reports. Journal of Business, Finance and Accounting, 20(4), 521-535.

Emirates Diary (2015). Islamic banks in UAE report. Retrieved September 19, 2017, from http://emiratesdiary.com/uae-tips/list-of-islamic-banksin-uae\#ixzz4OOVVgTyg.

Gray, R., Kouhy, R., \& Lavers, S. (1995). Corporate social and environmental reporting: A review of the literature and a longitudinal study of UK disclosure. Accounting,
Auditing \& Accountability Journal, 8(2), 47-77.

Gujarati, D., (2005). Basic econometrics (4th ed.). New York, NY: McGraw Hill.

Diamond, W. D., \& Verrecchia, R. E. (1991), Disclosure, liquidity, and the cost of capital. Journal of Finance, 14(1), 1325-1359.

Freeman, R. E. (1994). The politics of stakeholder theory: Some future directions. Business ethics quarterly, 4(4), 409-421.

Hassan, O. A. G., Romilly, P., Giorgioni, G., \& Power, D. (2009). The value relevance of disclosure: Evidence from the emerging market of Egypt. The International Journal of Accounting, 44(1), 79- 102.

Healy, P., Hutton, A., \& Palepu, K. (1999). Stock performance and intermediation changes surrounding sustained increases in disclosures. Contemporary Accounting Research, 16(3), 485-520.

Hirtle, B. (2007). Public disclosure, risk, and performance at Bank Holding Companies. (Federal Reserve Bank of New York Staff Reports No. 293).

Hussain M., Islam M., Gunasekaran A., \& Maskooki, K. (2002). A comparative study of accounting standards of financial institutions in GCC countries. International Journal of Management and Decision Making, 3(3/4), 243-255.

Hughes, P. J. (1986). Signalling by direct disclosure under asymmetric information. Journal of Accounting and Economics, 8(2), 119-142.

Jensen, M. C., \& Meckling, M. H. (1976). Theory of the firm: Managerial behavior, agency costs and ownership structure. Journal of Financial Economics, 20(2), 305360.

Lu, C., Liao, M. G., \& Yang, Y. C. (2007). Ownership structure, information disclosure and corporate value: An empirical analysis of Taiwan companies. Proceeding of the 13th Asia Pacific Management Conference, 698-704.

Ngo, P. T. H. (2006). Endogenous capital and profitability in banking. International Review of Finance, 6(3- 4), 99128.

Nier, E., \& Baumann, U. M. (2006). Market discipline, disclosure and moral hazard in banking. Journal of Financial Intermediation, 15(1), 332-361.

Ellili, N. O. D., \& Nobanee, H. (2017). Corporate risk disclosure of Islamic and conventional banks. Banks and Bank Systems, 12(3), 247-256. doi:10.21511/bbs.12(31).2017.09.

Nurul, H., \& Raudah, D. (2012). Disclosure, cost of capital and Islamic banks performance: A simultaneous equations approach. Proceedings of International conference on banking and finance, International Management Institute (IMI), 13-15.

Organization of the Petroleum Exporting Countries (OPEC) (2014). Annual Statistical Bulletin. Retrieved March 5, 2019, from https://www.opec. org/opec_web/static_files_project/ media/downloads/publications/ ASB2014.pdf

Peterson, C., \& Plenborg, T. (2006).Voluntary disclosure and 
information asymmetry in Denmark. Journal of International Accounting, Auditing and Taxation. doi:10.1016/j.intaccaudtax.2006.08.004.

Sengupta, P. (1998). Corporate disclosure quality and the Cost of Debt. The Accounting Review, 73(1), 459-474.

Srairi, S. (2015). Corporate governance disclosure practices and performance of Islamic banks in GCC countries. Journal of Islamic Finance, 4(2), 001-017.

Tabash, M. I., \& Dhankar, R. S. (2014a). The flow of Islamic finance and economic growth: An empirical evidence of Middle East. Journal of Finance and Accounting, 2(1), 11-19.

Tabash, M. I., \&. Dhankar, R. S. (2014b). Islamic banking and economic growth: A cointegration approach. The Romanian Economic Journal, 58, 61-90.

Wallace, R. S. O., \& Naser, K. (1995). Firm-Specific determinants of comprehensiveness of mandatory disclosure in the corporate annual reports of firms on the stock exchange in Hong Kong. Journal of Accounting and Public Policy, 14, 311-368. 